\title{
Inflation and Euro Membership
}

\author{
Johannes K. Dreyer ${ }^{1+}$ and Peter A. Schmid ${ }^{2}$ \\ ${ }^{1}$ Roskilde University, Denmark \\ ${ }^{2}$ FOM University of Applied Sciences, Germany
}

\begin{abstract}
This article aims to investigate the relation between Euro membership and inflation. We construct two models that explain inflation using nonmonetary variables. To estimate these models, we collect yearly panel data for the 28 members of the European Union from 1998 to 2016. Due to the problem of endogeneity associated with some variables, we use the panel GMM following Arellano and Bond (1991) to perform all estimations. Results for the estimations of coefficients do not indicate a relation between membership in the Eurozone and inflation rates, neither for the short nor long term. Thus, the results can be considered contra-evidence for statements that the Euro increases short term inflation of its new members or that it reduces long term inflation rates permanently.
\end{abstract}

Keywords: Inflation Change, Economic integration, EU and EZ memberships, Euro Effects

JEL Classifications: F15, F33, F43, O52

Received 30 July 2019, Revised 1 April 2020, Accepted 7 April 2020

\section{Introduction}

Membership in currency unions is usually marketed with promises of lower inflation rates. However, the general public in Euro countries complained about price hikes with the introduction of the common currency (Shiamptanis, 2010). In Germany, for example, this could be observed in the so-called TEURO summits at the highest political levels ${ }^{1}$. However, after the introduction of the Euro, even though the perceived inflation increased, official figures for it were not considerably higher than in prior years (Jungermann et al., 2007). The perception of higher inflation might have discouraged other countries from joining the Eurozone (EZ).

This article aims to identify the overall short and long term effects of EZ membership on inflation rates. Thus, our study contributes to the discussion on price impacts of membership in currency unions and serves as a possible guideline for countries that are uncertain about joining the EZ, are already members of the EZ and discussing a possible exit, and are planning to share a currency, such as the nascent common currency areas in Africa.

\footnotetext{
+Corresponding Author: Johannes K. Dreyer

Associate Professor of Financial Economics, Roskilde University, Universitetsvej 1, building 25.1, 4000, Roskilde, Denmark. Tel: +45 4674 3293, Email: jodreyer@ruc.dk

Co-Author: Peter A. Schmid

Professor of Finance and Entrepreneurship, FOM University of Applied Sciences, Arnulfstr. 30, 80335, Munich, Germany.
} 
Conforming to the criteria of Mundell (1961), there are many studies questioning if the EZ can be considered as an optimal currency area and also questioning the viability of the Euro without a complete fiscal federalism among its member countries (Dreyer \& Schmid, 2015; Kalemli-Ozcan, Sørensen \& Yosha, 2001; Kenen, 1995; Krugman, 1991, 1993). Others try to measure the impacts of membership in the European Union (EU) or Eurozone (EZ) on trade (Baldwin, 1992; Baldwin \& Taglioni, 2007; Berger \& Nitsch, 2008; Bun \& Klaassen, 2002, 2007; Rose, 2000). Meanwhile, some others investigate the effects of EU/EZ membership on economic growth (Badinger, 2005; Crespo Cuaresma et al., 2008; Dreyer \& Schmid, 2017; Henrekson et al., 1997; Landau, 1995; Mann, 2015; Vanhoudt, 1999). Very few articles study the overall effects of EZ membership on inflation.

Studies on this issue have common conclusions. For example, Shiamptanis (2010) found evidence of a structural break in inflation rates for countries that joined the EZ in 1999. He identified higher inflation rates just after the Euro's introduction relative to prior periods. This structural break was also identified in Latvia by Cavallo et al. (2015), who used an international store chain operating within the country to show that prices were adjusted to German levels after the introduction of the Euro.

In the long term, however, membership in a currency union is associated with lower inflation rates and synchronization (Cham, 2011; Kishor \& Ssozi, 2010). As stated by Windberger and Zeileis (2014), this is observed for the EZ, where the decrease in mean inflation rates took place with a sharp reduction of skewness, i.e., by synchronization of rates in the run-up to the EZ and decreasing rates in previously higher inflation countries. However, according to Duarte (2003) and Hall and Lagoa (2014), EZ members experienced diverging inflation rates in the first years of the Euro 2 ).

Some further articles study inflation rates in the EZ (Angeloni \& Ehrmann, 2007; Altissimo et al., 2011; Hristov et al., 2014). However, these articles focus on the explanation of inflation differentials within EZ members and not directly on the relationship between EZ membership and inflation. Angeloni and Ehrmann (2007) show that inflation differentials have been falling sharply during the 1990s and stabilized already before the Euro adoption in 1999. Thus, for the 28 members of the EU, the tendency of decreasing inflation rates was already present.

Comparing inflation rates of EZ members before and after 1999 and concluding that EZ membership permanently decreases inflation rates may be questionable because these rates also decreased for other EU countries that did not join the common currency from the beginning. So, in contrast to the literature, this article assumes a structural break in inflation rates during the 1990s and does not use data before 1998. Doing so it avoids the study of short term hikes in prices for the $1999 \mathrm{EZ}$ entrants, which was analyzed and confirmed by the literature.

1) In the word Teuro, the prefix " $T$ " means teuer, German word for expensive.

2) For a summary of the literature on inflation effects of membership of currency unions, see Appendix 1. 
We model inflation with different nonmonetary variables such as GDP growth, unemployment rates, government spending, investment, total government debt, current account balance, and balance of the government budget as proposed by other articles (Cottarelli et al., 1998; Fakher, 2016; Hammermann \& Flanagan, 2009). We use two different dummy variables to account for two possible effects of EZ membership on inflation.

An announcement dummy, which assumes the value of one during the years before joining the Euro, measures the short term level effect in prices due to joining the EZ. One to three years prior the date of membership are used to account for people's expectations of joining the Euro.

A membership dummy, which assumes the value of one when a country is officially a member of the EZ, measures the long term effect of membership on inflation rates in comparison to countries that are not members.

Two different models that explain inflation are used. In the first, all aforementioned variables are included. However, some variables such as government spending can be seen as a channel by which Euro membership affects inflation because part of what is spent by the government could be influenced or restricted by membership. Thus, regressing inflation with a membership dummy while simultaneously controlling for these channel variables, could be problematic. One could ask which effect on inflation is left for the dummy variable, when all these channel variables are included. Therefore, estimations without these variables are rerun.

Due to the problem of endogeneity associated with these variables (see Dreyer \& Schmid, 2017), we used the linear generalized method of moments (GMM), also known as difference GMM (Arellano \& Bond, 1991). We collected yearly data from Eurostat, OECD, and the International Monetary Fund from 1998 to 2016 for all 28 countries $^{3}$ ).

The results do not provide evidence of increases in prices due to joining the Euro after 1999 (short term effects) as both of our models do not suggest that Euro announcements lead to general level effects in prices. When analyzing the difference in inflation associated to membership (long term effects), the models provide no evidence that Euro members have lower inflation rates compared to nonmembers.

The outline of the paper is as follows: Section 2 formulates our models; Section 3 provides estimation results, and Section 4 concludes.

\section{Modeling Inflation}

To model inflation, we follow the literature on nonmonetary variables that are used to explain

3) For more details on our data, see Appendix 2. 
it (Cottarelli et al., 1998; Hammermann \& Flanagan, 2009; Fakher, 2016).

Typically, in the short term, higher real GDP growth is associated with higher inflation. The explanation for this is that higher growth is often driven by high growth in aggregate demand that induces growth in aggregate output and higher prices (Motley, 1998; Den Haan, 2000). To proxy this possible effect, we use the real growth of GDP as determinant of inflation rates. In contrast, if output expands faster than income, there is less pressure on the prices of goods and services. With this in mind, we also use the investment share of a country's GDP as an independent variable. The higher the level of investments, the higher should the change in aggregate supply of goods and services be, and, thus, the lower the inflation rates.

Unemployment could have two different effects on inflation. When unemployment rates are high and consumers have lower purchasing power, the inflation pressure should decrease. Additionally, the labor supply's negotiating power in wage setting is limited and provides less pressure on prices due to lower labor cost increases. Conversely, when unemployment is high, authorities may be tempted to make monetary expansions, even though agents anticipate this expansion and its effects on unemployment rates may be limited. This is sufficient to increase inflation rates. For the EU region and time frame of this study, we expect that higher unemployment rates should correlate with lower inflation. This should be true even for EU members that still have their own monetary policies since they have restrictive targets for inflation rates and little room for monetary expansions (Cottarelli et al., 1998).

In the case of the current account balance, the higher the deficit in current accounts, the higher one should expect the inflation rate. This occurs from governments devaluating their currencies to solve problems in their balance of payments. When a country has a current account deficit, its currency should lose value against foreign currencies. This exchange rate depreciation is seen as an automatic adjustment to the balance of payments. With a depreciated currency, prices tend to increase in domestic currency units. Thus, the higher the surplus in current account, the lower we expect the inflation rate. This reasoning is valid for non-EZ members, as long they still have their monetary policies4) (Cottarelli, 1998).

The balance of government budget, its total debt, and its total spending are used as explanatory variables. There are two reasons for using these variables: (1) For non-EZ countries, governments that have high deficits in their budgets, high amounts of debt, or simply spend too much may be tempted to solve part of their problems with inflation (seigniorage). (2) For all countries, there is also an inflationary effect of public spending if governments spend inefficiently or keep high expenditures during a period of income growth above the growth of output. For these reasons, we assume that the higher the deficit in the government budget, government

4) We decided to still include this variable, because it was possible during the time frame of our analysis to observe strong movements of exchange rates from non-EZ members against the Euro. However, we decided not to include openness of the economy because we believe that the facility for international trade in EU countries is very even, and, thus, this variable would not have a strong explanatory power of inflation. 
spending, and total debt, the higher the inflation (Hammermann and Flanagan, 2009).

These variables construct the first version of our model:

$$
\pi_{t, i}=\beta_{1} G r_{t, i}+\beta_{2} I N V_{t, i}+\beta_{3} S_{t, i}+\beta_{4} U_{t, i}+\beta_{5} C u r_{t, i}+\beta_{6} D E B T_{t, i}+\beta_{7} G O V_{t, i}+\beta_{8} E Z_{t, i}+\beta_{9} A n n_{t, i}
$$

where $\pi_{t, i}$ is the natural $\log$ of inflation for country $i$ in year $t, G r$ is the annual real growth rate of GDP, and $U$ is unemployment rate. The variables $I N V, S, C u r, D E B T$, and GOV refer to investment, balance of government budget, balance of current account, total size of public debt, and government spending, respectively, and are presented in percentage terms of each country's GDP.

The effect of EZ membership is further measured on inflation by using the dummy variable EZ. Thus, if EZ membership has a permanent effect on inflation, $\beta_{8}$ should be significant. The EZ dummy, however, does not account for short term effect on domestic prices, which may occur when a country announces to join the common currency. To deal with this possible effect, we also include the dummy variable Ann in the model, which assumes the value of one in the 3 years preceding the Euro adoption and zero otherwise. Since one could argue that the choice of 3 years for the announcement variable may be arbitrary, we also ran estimations assuming an announcement period of one and two years.

One may argue that there is empirical evidence (Cottarelli et al., 1998) that inflation is sometimes affected by past observations of our independent variables. Therefore, we could rewrite Eq. (1) including their lags. For example, past investment is expected to influence inflation negatively, while the opposite is expected for past inflation. Because of that, coefficients associated to these variables are expected to be negative and positive, respectively. However, variables such as unemployment, current account balance, government spending, and total domestic debt present a strong time series autocorrelation (correlations equal 0.93, 0.90, 0.95, and 0.97 , respectively). These variables in one period can be considered good proxies for themselves in the subsequent period, because they typically do not vary tremendously in the short term. Thus, their inclusion in two time periods in Eq. (2) would not add information to the model but inflate the variance of our estimations. Moreover, such a high autocorrelation between two variables would lead the correlation matrix to singularity and, thus, it would not be inversible, making GMM estimations impossible. To cope with this, these variables are used without their lags. We are careful not to include the lag of GDP growth in the model, since this effect, if present, should be only found in the short term.

To correct possible autoregressive effects of our dependent variable inflation, we also add its lag of order 1. In this case, the idea of adding past inflation to the model is to control for a possible "inertial inflation" that cannot be explained by the other controlling variables. Equation (2) describes Model 1, which considers these observations: 


$$
\begin{aligned}
\pi_{t, i}= & \beta_{1} G r_{t, i}+\beta_{2} I N V_{t, i}+\beta_{3} S_{t, i}+\beta_{4} U_{t, i}+\beta_{5} C u r_{t, i}+\beta_{6} D e b t_{t, i}+\beta_{7} G O V_{t, i} \\
& +\beta_{8} E Z_{t, i}+\beta_{9} A n n_{t, i}+\beta_{10} \pi_{t-1, i}+\beta_{11} I N V_{t-1, i}+\beta_{12} S_{t-1, i}
\end{aligned}
$$

We further use time dummies in estimations to account for possible time effects on inflation.

Notice that regressing inflation according to Eq. (2) where we control for variables such as government spending, investment, total debt, balance of government budget, and current account balance may create problems in the interpretation of the contribution of membership to inflation. As Dreyer and Schmid (2017) describe for the case of economic growth, by controlling these variables, we may similarly control many channels through which EZ membership or its announcement can influence inflation. For example, if government spending impacts inflation while simultaneously is a function of EZ membership or its announcement (e.g., EZ countries need to respect different rules regarding government spending), one can say that government expenditure is a valid channel through which EZ membership or its announcement affects inflation. In this case, controlling government spending takes in consideration part of the dummy effect on inflation. The same reasoning is valid for investment, total debt, balance of budget, and current account balance so that we will refer to them from now on as "channel variables."

Due to this issue concerning channel variables, we decided to estimate a more general model (Model 2), where they are not included based on the following equation:

$$
\pi_{t, i}=\beta_{1} G r_{t, i}+\beta_{4} U_{t, i}+\beta_{8} E Z_{t, i}+\beta_{9} A n n_{t, i}+\beta_{10} \pi_{t-1, i}
$$

In the next session, we will estimate both models, where the first includes all variables as in Eq. (2) and the second disregards channel variables as in Eq. (3). As a result, in the first model, membership effects on inflation are restricted to those not coming from the channel variables. We would thus expect the parameter of membership on inflation and its announcement to be stronger in the second model, where the dummies do not share any effect on inflation with other independent variables.

\section{Measuring the Impact of EZ Membership on Inflation}

\section{A. Initial estimations}

To join the common currency, countries must meet many conditions, including inflation targets. Thus, in our equations, the dummy variables do not follow a random process. The membership variables can be considered endogenous in Eqs. (2) and (3), since they might be explained by other latent variables. In this case, the two models cannot be consistently 
estimated without the use of instrumental variables (see Bun \& Klaassen, 2007). The same argument is valid for most of our other independent variables, so we use the GMM following Arellano and Bond (1991) to run all estimations. Due to the finite sample bias related to the GMM, one could suggest the use of the system GMM of Blundell and Bond (1998) instead. It has the advantage to generate less bias even though it uses more instruments. However, to use it, the number of instruments should be lower than the number of individuals, which is not possible in our case 5 ).

It is important to observe that in our data sample, the longer the period, the more EZ members exist, and so one can expect to observe a time trend, which could bias estimation results. However, the time frame used by our study is not long so that this problem is neglectable. For a detailed discussion on time trends and their associated bias, see Baldwin and Taglioni (2007) and Bun and Klaassen (2007).

Another issue for the consistency of estimations could be the existence of unit roots. Dreyer (2012) and Dreyer et al. (2013) discuss the importance of stationarity for GMM estimations. Although our data has a restricted time frame and the likelihood of finding such a problem is low, we conducted some tests that ensure panel stationarity of all variables (see Appendix 3).

We used instruments of lag 3 for both estimations of Models 1 and 2. The initial results for GMM estimations can be found in Table 1. Estimations perform well with no indication of second-order autocorrelation of residuals and no rejection of the Hansen-Sargan test. The Wald tests confirm that our independent variables and time dummies are significant to explain inflation.

To be conservative, we follow White (1980) and Newey and West (1987) and use for all tests of significance the HAC method (heteroscedasticity autocorrelation consistent) to make sure that the standard errors of the coefficients are robust to heteroscedasticity and autocorrelation. We are conscious that by using such corrections, we lose precision and may find wider confidence intervals6).

Another important observation is that we decided not to reestimate our models without nonsignificant variables. The nonsignificant coefficients are left because of the problem described by Hendry and Krolzig (2004). These authors show that inference tests may strongly depend on the ordering in which we delete the nonsignificant variables.

Model 1 controls for the channel variables. In this model, $\beta_{4}, \beta_{6}$, and $\beta_{10}$ are significant

5) A detailed comparison of these GMM techniques is offered by Roodman (2009), and a lucid discussion on the choice of GMM technique in a similar data setting is offered by Dreyer and Schmid (2017).

6) One could also point out the possibility of cross-sectional correlation of disturbances as a possible issue of the GMM estimation. If this cross-correlation is high, GMM estimates lose consistency, and results cannot be trusted. In order to visualize the possibility of this problem, we study the cross-correlation of disturbances of our estimated models which for both are in average in the order of 0.3. Even though a correlation exists, we can argue that it is low. 
at the $10 \%$ level. $\beta_{4}$ is negative implying that the higher the unemployment, the lower the inflation rate. $\beta_{6}$ and $\beta_{10}$ indicate that the higher the debt and past inflation, the higher the inflation rate.

There is no evidence that $\beta_{1}$ (economic growth), $\beta_{2}$ (investment), $\beta_{3}$ (surplus in the budget

Table 1. GMM estimation results

\begin{tabular}{|c|c|c|c|c|c|c|c|}
\hline \multirow[b]{3}{*}{$\beta$} & \multirow[b]{3}{*}{ Variables } & \multicolumn{3}{|c|}{ Model 1} & \multicolumn{3}{|c|}{ Model 2} \\
\hline & & \multicolumn{3}{|c|}{ Coef. } & \multicolumn{3}{|c|}{ Coef. } \\
\hline & & Ann 3 & Ann 2 & Ann 1 & Ann 3 & Ann 2 & Ann 1 \\
\hline$\beta_{1}$ & $G r_{t, i}$ & $\begin{array}{c}0.00018 \\
(0.00045)\end{array}$ & $\begin{array}{c}0.00022 \\
(0.00046)\end{array}$ & $\begin{array}{c}0.00021 \\
(0.00046)\end{array}$ & $\begin{array}{c}0.00018 \\
(0.00037)\end{array}$ & $\begin{array}{c}0.00023 \\
(0.00040)\end{array}$ & $\begin{array}{c}0.00022 \\
(0.00039)\end{array}$ \\
\hline$\beta_{2}$ & $I N V_{t, i}$ & $\begin{array}{l}-0.00018 \\
(0.00110)\end{array}$ & $\begin{array}{l}-0.00026 \\
(0.00111)\end{array}$ & $\begin{array}{l}-0.00024 \\
(0.00109)\end{array}$ & $\mathrm{x}$ & $\mathrm{x}$ & $\mathrm{x}$ \\
\hline$\beta_{3}$ & $S_{t, i}$ & $\begin{array}{l}-0.00091 \\
(0.00056)\end{array}$ & $\begin{array}{l}-0.00084 \\
(0.00055)\end{array}$ & $\begin{array}{l}-0.00086 \\
(0.00055)\end{array}$ & $\mathrm{x}$ & $\mathrm{x}$ & $\mathrm{x}$ \\
\hline$\beta_{4}$ & $U_{t, i}$ & $\begin{array}{c}-0.00314 \\
* * *(0.00073)\end{array}$ & $\begin{array}{c}-0.00330 \\
* * *(0.00083)\end{array}$ & $\begin{array}{c}-0.00327 \\
* * *(0.00084)\end{array}$ & $\begin{array}{c}-0.00217 \\
* * *(0.00057)\end{array}$ & $\begin{array}{c}-0.00223 \\
* * *(0.00061)\end{array}$ & $\begin{array}{c}-0.00221 \\
* * *(0.00060)\end{array}$ \\
\hline$\beta_{5}$ & Curr $_{t, i}$ & $\begin{array}{l}-0.00049 \\
(0.00046)\end{array}$ & $\begin{array}{l}-0.00045 \\
(0.00045)\end{array}$ & $\begin{array}{l}-0.00046 \\
(0.00045)\end{array}$ & $\mathrm{x}$ & $\mathrm{x}$ & $\mathrm{x}$ \\
\hline$\beta_{6}$ & $D E B T_{t, i}$ & $\begin{array}{c}0.00022 \\
.(0.00012)\end{array}$ & $\begin{array}{c}0.00019 \\
.(0.00011)\end{array}$ & $\begin{array}{c}0.00019 \\
.(0.00011)\end{array}$ & $\mathrm{x}$ & $\mathrm{x}$ & $\mathrm{x}$ \\
\hline$\beta_{7}$ & $G O V_{t, i}$ & $\begin{array}{c}0.00122 \\
(0.00257)\end{array}$ & $\begin{array}{c}0.00087 \\
(0.00244)\end{array}$ & $\begin{array}{c}0.00086 \\
(0.00247)\end{array}$ & $\mathrm{x}$ & $\mathrm{x}$ & $\mathrm{x}$ \\
\hline$\beta 8$ & $E Z_{t, i}$ & $\begin{array}{c}0.01929 \\
.(0.01034)\end{array}$ & $\begin{array}{c}0.00514 \\
(0.00782)\end{array}$ & $\begin{array}{c}0.00496 \\
(0.00602)\end{array}$ & $\begin{array}{l}0.01476 \\
0.01184\end{array}$ & $\begin{array}{c}0.01929 \\
(0.01034)\end{array}$ & $\begin{array}{c}0.00283 \\
(0.00639)\end{array}$ \\
\hline$\beta_{9}$ & $A n n_{t, i}$ & $\begin{array}{c}0.01533 \\
(0.01082)\end{array}$ & $\begin{array}{c}0.00051 \\
(0.00918)\end{array}$ & $\begin{array}{c}0.00164 \\
(0.00850)\end{array}$ & $\begin{array}{c}0.01018 \\
(0.01062)\end{array}$ & $\begin{array}{l}-0.00403 \\
(0.00934)\end{array}$ & $\begin{array}{l}-0.00212 \\
(0.00836)\end{array}$ \\
\hline$\beta_{10}$ & $\pi_{t-1, i}$ & $\begin{array}{c}0.55585 \\
* * * 10.16318)\end{array}$ & $\begin{array}{c}0.53278 \\
* \div(0.17522)\end{array}$ & $\begin{array}{c}0.53362 \\
* *(0.17352)\end{array}$ & $\begin{array}{c}0.55557 \\
* *(0.18225)\end{array}$ & $\begin{array}{c}0.53504 \\
* *(0.19459)\end{array}$ & $\begin{array}{c}0.53750 \\
* *(0.19100)\end{array}$ \\
\hline$\beta_{11}$ & $I N V_{t-1, i}$ & $\begin{array}{l}-0.00048 \\
(0.00091)\end{array}$ & $\begin{array}{l}-0.00062 \\
(0.00094)\end{array}$ & $\begin{array}{l}-0.00060 \\
(0.00095)\end{array}$ & $\mathrm{x}$ & $\mathrm{x}$ & $\mathrm{x}$ \\
\hline$\beta_{12}$ & $S_{t-1, i}$ & $\begin{array}{l}-0.00050 \\
(0.00044)\end{array}$ & $\begin{array}{l}-0.00047 \\
(0.00045)\end{array}$ & $\begin{array}{l}-0.00047 \\
(0.00043)\end{array}$ & $\mathrm{x}$ & $\mathrm{x}$ & $\mathrm{x}$ \\
\hline Hanse & Sargan (df. 32) & 0.9096 & 0.9257 & 0.9243 & 0.9863 & 0.9912 & 0.9918 \\
\hline $\mathrm{Au}$ & or. Test (1) & $-2.71 * *$ & $-2.61 * *$ & $-2.67 * *$ & $-2.59 * *$ & $-2.46^{*}$ & $-2.56^{*}$ \\
\hline $\mathrm{Au}$ & or. Test (2) & -1.36 & -1.37 & -1.41 & -1.61 & -1.55 & -1.36 \\
\hline & ald Coef & $216.26^{* * *}$ & $232.92 * * *$ & $209.55 * * *$ & $42.47 * * *$ & $34.57 * * *$ & $216.26^{* * *}$ \\
\hline $\mathrm{Wa}$ & Time Dum & $253.68 * * *$ & $243.01 * * *$ & $242.63 * * *$ & $346.01 * * *$ & $295.81 * * *$ & $253.68 * * *$ \\
\hline
\end{tabular}

(Notes) (i) Ann 3, Ann 2, and Ann 1 indicate that the announcement variable in the regression computes the prior three, two, and one years, respectively, before effective Euro membership.

(ii) Vectors of instruments are constituted of lags of order 3. We use lags of the dependent variable and GDP growth as external instruments and lags of all other independent variables in levels and differences as endogenous instruments. Significant coefficients are marked in bold.

(iii) Significance: "." for $p$-value $<10 \%$, "**" $<5 \%$, "***" $<1 \%$, and " ****" $<0.1 \%$

(iv) $\mathrm{x}$ for variables not included in the model and () indicates standard error.

(Source) author's calculations 
of the government), $\beta_{5}$ (current balance), $\beta_{7}$ (government spending), $\beta_{11}$ (past investment) and $\beta_{12}$ (past surplus in the budget of the government) affect current inflation.

We do not find evidence according to Model 1 that the coefficients $\beta_{8}$ (Euro membership) and $\beta_{9}$ (EZ Announcement) are significant. Therefore, the model does not indicate any influence of Euro membership or its announcement on inflation.

One could question the results by mentioning the problem of the channel variables and the consequent underestimation of the effects of different explanatory variables on inflation, including membership effects. In this case, these variables could be seen as the mechanism through which membership affects inflation. For example, this could be the explanation for why neither the coefficient for current nor lag investment is significant. Thus, to have a broader understanding on the effects of EZ membership and its announcement on inflation, we need to run estimations without them. That was done in Model 2.

In Model 2, $\beta_{4}$ and $\beta_{10}$ are significant at the 5\% level. $\beta_{4}$ is negative, implying that the higher the unemployment rate, the lower the inflation will be. On the other hand, $\beta_{10}$ indicates that the higher the past inflation, the higher the current inflation will be.

There is no evidence that GDP growth affects current inflation ( $\beta_{1}$ not significant). We do not find any evidence according to Model 2 that the coefficients $\beta_{8}$ (Euro membership) and $\beta_{9}$ (EZ Announcement) are significant. Thus, the model does not indicate any influence of Euro membership or its announcement on inflation.

\section{B. Robustness and multicollinearity}

We test the robustness of our estimates by running simple regressions of inflation on each of the independent variables used in the models. We use both panel regression methods, pooling, and fixed effects. Table 2 reports the estimated slopes for these regressions.

We can verify a problem related to the robustness of estimates in Model 1 . The coefficient related to debt is significant, but positive, when simple regressions of inflation on debt indicate the opposite sign. Moreover, there are many estimates related to variables that are expected to determine inflation that lack significance. Many of these nonsignificant variables also have the "wrong signs" when compared to those obtained via simple regressions.

Change in signals and lack of significance of estimates in Model 1 that is overall significant can be seen as a clear indication of multicollinearity (Dreyer \& Schmid, 2020). That is why we decided to calculate the variance inflation factors (VIFs) for the variables. Table 2 has different variables with VIFs higher than 37 ). These higher VIFs are avoided by removing from model estimations the lags of investment and balance of the government $\left(I N V_{t-1, i}\right.$ and $\left.S_{t-1, i}\right)$.

7) As argued by Dreyer and Schmid (2020), in practice, values of VIF significantly higher than 2 could already indicate multicollinearity. Here, conservatively, we only cut those variables that present VIFs higher than 3 . 
When comparing the results in Table 2 with those estimates of Model 2 in Table 1, we cannot verify any change in sign. Moreover, all VIFs for the independent variables used in Model 2 are low. This leads us to conclude that there is no evidence of a lack of robustness in the estimates of this model.

Table 2. Simple regressions and VIFs

\begin{tabular}{|c|c|c|c|c|c|}
\hline \multirow{2}{*}{ Variable } & \multicolumn{2}{|c|}{ Simple Regressions: Slope } & \multicolumn{3}{|c|}{ VIFs } \\
\hline & Fixed Effects & Pooling & All & $-I N V_{t-1, i}$ & $-S_{t-1, i}$ \\
\hline$G r_{t, i}$ & $\begin{array}{c}0.0002 \\
(0.0004)\end{array}$ & $\begin{array}{c}0.0012 \\
* *(0.0004)\end{array}$ & 2.30 & 1.54 & 1.46 \\
\hline$I N V_{t, i}$ & $\begin{array}{c}0.0016 \\
* * *(0.0004)\end{array}$ & $\begin{array}{c}0.0020 \\
* * *(0.0003)\end{array}$ & 8.85 & 2.30 & 2.28 \\
\hline$S_{t, i}$ & $\begin{array}{l}-0.0003 \\
(0.0005)\end{array}$ & $\begin{array}{l}-0.0003 \\
(0.0005)\end{array}$ & 3.23 & 3.06 & 1.61 \\
\hline$U_{t, i}$ & $\begin{array}{c}-0.0015 \\
* *(0.0005)\end{array}$ & $\begin{array}{l}-0.0005 \\
(0.0004)\end{array}$ & 1.34 & 1.33 & 1.28 \\
\hline Curr $_{t, i}$ & $\begin{array}{c}-0.0022 \\
* * *(0.0003)\end{array}$ & $\begin{array}{c}-0.0021 \\
* * *(0.0002)\end{array}$ & 1.25 & 1.95 & 1.94 \\
\hline$D E B T_{t, i}$ & $\begin{array}{c}-0.0004 \\
* * *(0.0001)\end{array}$ & $\begin{array}{c}-0.0003 \\
* * *(0.0000)\end{array}$ & 1.77 & 1.65 & 1.56 \\
\hline$G O V_{t, i}$ & $\begin{array}{l}-0.0007 \\
(0.0011)\end{array}$ & $\begin{array}{c}-0.0030 \\
* * *(0.0006)\end{array}$ & 1.25 & 1.23 & 1.23 \\
\hline$\pi_{t-1, i}$ & $\begin{array}{c}0.1488 \\
* * *(0.0117)\end{array}$ & $\begin{array}{c}0.1849 \\
* * *(0.0123)\end{array}$ & 1.06 & 1.04 & 1.04 \\
\hline$I N V_{t-1, i}$ & $\begin{array}{c}0.0014 \\
* * *(0.0004)\end{array}$ & $\begin{array}{c}0.0018 \\
* * *(0.0003)\end{array}$ & 7.28 & $\mathrm{x}$ & $\mathrm{x}$ \\
\hline$S_{t-1, i}$ & $\begin{array}{c}0.0004 \\
(0.0005)\end{array}$ & $\begin{array}{c}-0.0003 \\
0.0005\end{array}$ & 3.09 & 3.02 & $\mathrm{x}$ \\
\hline
\end{tabular}

(Notes) (i) Significance: '?' for $p$-value $<10 \%$, '*' $<5 \%$, '**' $<1 \%$, and ' $* * *$ ' $<0.1 \%$

(ii) $\mathrm{x}$ for variables not included in the model and () indicates standard error.

(Source) Author's calculations

\section{Reestimating model 1}

We reestimated Model 1, ignoring the lag variables $I N V_{t-1, i}$ and $S_{t-1, i}$. We used instruments of lag 3 in all estimations presented in Table 3. We do not verify any indication of second-order autocorrelation of residuals, and the Hansen-Sargan test does not reject that identification requirements are met in all estimations. The Wald tests confirm that independent variables and time dummies are significant to explain inflation. All inference results use the HAC method to ensure that the variances of coefficients are robust to heteroscedasticity and autocorrelation.

Except for the estimate related to $D E B T_{t, i}$, all significant coefficients $\beta_{3}, \beta_{4}$, and $\beta_{10}\left(S_{t, i}\right.$, $\left.U_{t, i}, \pi_{t-1, i}\right)$ have signs that go in line with those that were found with simple regressions. Since the coefficient related to debt has the wrong sign, estimations for Model 1 without this variable 
are done. In this case, all significant estimates $\beta_{3}, \beta_{4}, \beta_{5}$, and $\beta_{10}\left(S_{t, i}, U_{t, i}, \operatorname{Curr}_{t, i}, \pi_{t-1, i}\right)$ have signs that go in line with those found in our simple regressions.

Regardless of model setting, according to results, neither EZ membership nor its announcement plays a significant role in inflation rates. In the short term, the results diverge from those of Cavallo et al. (2015) who identified positive short-term effects of membership

Table 3. GMM estimation results

\begin{tabular}{|c|c|c|c|c|c|c|c|}
\hline \multirow[b]{4}{*}{$\beta$} & \multirow[b]{4}{*}{ Variables } & \multicolumn{6}{|c|}{ Model 1 - After VIF Corrections } \\
\hline & & \multicolumn{3}{|c|}{ Including Debt } & \multicolumn{3}{|c|}{ Removing Debt } \\
\hline & & \multicolumn{3}{|c|}{ Coef. } & \multicolumn{3}{|c|}{ Coef. } \\
\hline & & Ann 3 & Ann 2 & Ann 1 & Ann 3 & Ann 2 & Ann 1 \\
\hline$\beta_{1}$ & $G r_{t, i}$ & $\begin{array}{c}0.00031359 \\
(0.00046)\end{array}$ & $\begin{array}{c}0.00041 \\
(0.00052)\end{array}$ & $\begin{array}{c}0.00039 \\
(0.00052)\end{array}$ & $\begin{array}{c}0.00039 \\
(0.00048)\end{array}$ & $\begin{array}{c}0.00048 \\
(0.00053)\end{array}$ & $\begin{array}{c}0.00046 \\
(0.00052)\end{array}$ \\
\hline$\beta_{2}$ & $I N V_{t, i}$ & $\begin{array}{l}-0.00051 \\
(0.00096)\end{array}$ & $\begin{array}{l}-0.00069 \\
(0.00096)\end{array}$ & $\begin{array}{l}-0.00065 \\
(0.00094)\end{array}$ & $\begin{array}{l}-0.00068 \\
(0.00096)\end{array}$ & $\begin{array}{l}-0.00084 \\
(0.00096)\end{array}$ & $\begin{array}{l}-0.00081 \\
(0.00094)\end{array}$ \\
\hline$\beta_{3}$ & $S_{t, i}$ & $\begin{array}{r}-0.00092 \\
.(0.00055)\end{array}$ & $\begin{array}{l}-0.00086 \\
(0.00052)\end{array}$ & $\begin{array}{l}-0.00089 \\
.(0.00054)\end{array}$ & $\begin{array}{l}-0.00094 \\
.(0.00056)\end{array}$ & $\begin{array}{l}-0.00088 \\
(0.00053)\end{array}$ & $\begin{array}{l}-0.00091 \\
.(0.00054)\end{array}$ \\
\hline$\beta_{4}$ & $U_{t, i}$ & $\begin{array}{c}-0.00281 \\
* * *(0.00059)\end{array}$ & $\begin{array}{c}-0.00292 \\
* * *(0.00068)\end{array}$ & $\begin{array}{c}-0.00290 \\
* * *(0.00068)\end{array}$ & $\begin{array}{c}-0.00240 \\
* * *(0.00054)\end{array}$ & $\begin{array}{c}-0.00256 \\
* * *(0.00064)\end{array}$ & $\begin{array}{c}-0.00252 \\
* * *(0.00062)\end{array}$ \\
\hline$\beta_{5}$ & Curr $_{t, i}$ & $\begin{array}{l}-0.00056 \\
(0.00038)\end{array}$ & $\begin{array}{l}-0.00054 \\
(0.00036)\end{array}$ & $\begin{array}{l}-0.00054 \\
(0.00036)\end{array}$ & $\begin{array}{r}-0.00070 \\
.(0.00038)\end{array}$ & $\begin{array}{l}-0.00067 \\
.(0.00036)\end{array}$ & $\begin{array}{l}-\mathbf{0 . 0 0 0 6 7} \\
.(0.00036)\end{array}$ \\
\hline$\beta_{6}$ & $D E B T_{t, i}$ & $\begin{array}{c}0.00025 \\
*(0.00011)\end{array}$ & $\begin{array}{c}0.00022 \\
*(0.00010)\end{array}$ & $\begin{array}{c}0.00023 \\
*(0.00010)\end{array}$ & $\mathrm{x}$ & $\mathrm{x}$ & $\mathrm{x}$ \\
\hline$\beta_{7}$ & $G O V_{t, i}$ & $\begin{array}{c}0.00144 \\
(0.00251)\end{array}$ & $\begin{array}{c}0.00110 \\
(0.00237)\end{array}$ & $\begin{array}{c}0.00108 \\
(0.00241)\end{array}$ & $\begin{array}{c}0.00141 \\
(0.00249)\end{array}$ & $\begin{array}{l}0.001082 \\
(0.00235)\end{array}$ & $\begin{array}{c}0.00108 \\
(0.00239)\end{array}$ \\
\hline$\beta_{8}$ & $E Z_{t, i}$ & $\begin{array}{c}0.02008 \\
.(0.01177)\end{array}$ & $\begin{array}{c}0.00574 \\
(0.00894)\end{array}$ & $\begin{array}{c}0.00561193 \\
(0.00664)\end{array}$ & $\begin{array}{c}0.01774 \\
(0.01143)\end{array}$ & $\begin{array}{c}0.00381 \\
(0.00879)\end{array}$ & $\begin{array}{c}0.00383 \\
(0.00645)\end{array}$ \\
\hline$\beta_{9}$ & $A n n_{t, i}$ & $\begin{array}{c}0.01588 \\
(0.01148)\end{array}$ & $\begin{array}{c}0.00063 \\
(0.00938)\end{array}$ & $\begin{array}{c}0.00184 \\
(0.00861)\end{array}$ & $\begin{array}{c}0.01438 \\
(0.01118)\end{array}$ & $\begin{array}{l}-0.00057 \\
(0.00913)\end{array}$ & $\begin{array}{c}0.00062 \\
(0.00826)\end{array}$ \\
\hline$\beta_{10}$ & $\pi_{t-1, i}$ & $\begin{array}{l}0.55974508 \\
* *(0.17269)\end{array}$ & $\begin{array}{c}0.53720 \\
* *(0.18552)\end{array}$ & $\begin{array}{c}0.53789 \\
* *(0.18365)\end{array}$ & $\begin{array}{c}0.56736 \\
* *(0.17484)\end{array}$ & $\begin{array}{c}0.54465 \\
* *(0.18665)\end{array}$ & $\begin{array}{c}0.54579 \\
* * \\
(0.18440)\end{array}$ \\
\hline$\beta_{11}$ & $I N V_{t-1, i}$ & $\mathrm{x}$ & $\mathrm{x}$ & $\mathrm{x}$ & $\mathrm{x}$ & $\mathrm{x}$ & $\mathrm{x}$ \\
\hline$\beta_{12}$ & $S_{t-1, i}$ & $\mathrm{x}$ & $\mathrm{x}$ & $\mathrm{x}$ & $\mathrm{x}$ & $\mathrm{x}$ & $\mathrm{x}$ \\
\hline Hanse & Sargan (df. 32) & 0.9195 & 0.9376 & 0.9357 & 0.9348 & 0.9496 & 0.9482 \\
\hline Aut & or. Test (1) & $-2.70 * *$ & $-2.59 \div$ & $-2.66 * *$ & $-2.69 *$ & $-2.58 * *$ & $-2.66^{* *}$ \\
\hline Aut & or. Test (2) & -1.38 & -1.38 & -1.44 & -1.37 & -1.37 & -1.42 \\
\hline & ld Coef. & $145.92 * * *$ & $172.32 * * *$ & $179.69 * *$ & $162.34 * * *$ & $163.69 * * *$ & $184.18 \div * *$ \\
\hline Wa & Time Dum. & $366.92 * * *$ & $327.57 * * *$ & $375.71 * * *$ & $378.67 * * *$ & $330.22 * * *$ & $375.58 * * *$ \\
\hline
\end{tabular}

(Notes) (i) Ann 3, Ann 2, and Ann 1 indicate that the announcement variable in the regression computes the prior three, two, and one years, respectively, before effective Euro membership.

(ii) Vectors of instruments are constituted of lags of order 3. We use lags of the dependent variable and GDP growth as external instruments and lags of all other independent variables in levels and differences as endogenous instruments. Significant coefficients are marked in bold.

(iii) Significance: '?' for $p$-value $<10 \%$, ' $*$ ' $<5 \%$, '**' $<1 \%$, and ' $* * *$ ' $<0.1 \%$

(iv) $\mathrm{x}$ for variables not included in the model and () indicates standard error.

(Source) author's calculations 
on inflation rates in Latvia. However, our work does not concentrate on a single period or country as it is the case with Latvia. Our models give a general understanding of the relationship between membership and short term inflation for all different European countries. Unlike Shiamptanis (2010), who confirmed higher inflation rates for the first countries that joined the Euro in 1999, we do not find evidence to support this effect afterward.

Moreover, our results go in line with the findings of Angeloni and Ehrmann (2007), who show that inflation differentials have been falling sharply during the 1990s and stabilized already before the Euro adoption in 1999 for all 28 EU members, so that the tendency of decreasing inflation rates was already gone when the Euro was launched. As shown in the estimations, member countries did not have a permanently lower inflation than nonmembers if we consider only the time post EZ creation. This result goes in line with the existence of a structural break in inflation rates during the 1990s for the entire region and not only Euro members. To some extent, the event of the Euro creation may have contributed to this process to the entire region, including nonmembers. Thus, our results contradict the notion that membership in a currency union is associated with lower inflation as shown by Cham (2011), Kishor and Ssozi (2010), and Windberger and Zeileis (2014).

\section{Conclusion}

Our aim with this work was to investigate whether EZ membership or its announcement had any influence on inflation rates in the period from the adoption of the Euro to 2016.

We collected yearly data from the 28 EU countries from Eurostat, OECD, and the International Monetary Fund from 1998 to 2016. We build two models that explain inflation in two different ways. The first used channel variables that can be seen as mechanisms through which Euro membership affects inflation. The second model did not use these variables.

Given the problem of endogeneity associated with our models, we used the difference GMM of Arellano and Bond (1991) to perform estimations. Our results lead to two main conclusions.

First, even though the literature shows for some initial EZ countries that short term inflation effects should be observed when a country joins the Euro (Shiamptanis, 2010), this should not be the general expectation for countries that join after 1999. The lack of significance of the short term variable "announcement" provides evidence. Thus, in general, European countries should not fear price hikes from joining the Euro.

Second, our results provide evidence against part of the literature that supports permanent differentials in inflation due to EZ membership (see Windberger \& Zeileis, 2014). The variable $E Z$ is not significant showing that there are no inflation differentials among the $28 \mathrm{EU}$ countries due to adopting the Euro ${ }^{8}$. The discrepancy in the literature may be explained by the data 
period selected by our sample from 1998 to 2016 (post-Euro adoption). According to Angeloni and Ehrmann (2007), inflation rates and their differentials decreased sharply before the Euro in the 1990s. Thus, when restricting the data sample only to the period of the EZ, we find evidence that the Euro did not lead to lower inflation rates compared to those countries that continued to adopt their own national currencies. The event of the Euro may have reduced inflation rates in the entire EU region and not only in countries that joined the EZ in 1999. In this case, contrary to Cham (2011), Kishor and Ssozi (2010), and Windberger and Zeileis (2014), membership in a currency union does not necessarily imply lower inflation rates 9 ).

In summary, for countries joining the EZ after 1999, the occurrence of higher inflation rates as consequence of joining the EZ is an exception of what we should expect. Likely, because of the period of the analysis (post-Euro adoption) and because inflation rates were already converging in Europe before the Euro adoption, our work does not confirm the long-run stylized facts of lower long-run inflation contained in the literature.

Furthermore, we verified in our model a significant and positive effect of the lag of inflation in current inflation rates. Contrarily, variables such as unemployment rate, the budget of the government, and current account decrease inflation. This goes in accordance to the literature (Cottarelli et al., 1998; Fakher, 2016).

\section{References}

Altissimo, F., Benigno, P., \& Palenzuela, D. R. (2011). Inflation Differentials in a Currency Area: Facts, Explanations and Policy. Open Economies Review, 22, 189-233.

Angeloni, I., \& Ehrmann, M. (2007). Euro area inflation differentials. The B. E. Journal of Macroeconomics, $7(1)$, Article 24.

Arellano, M., \& Bond, S. (1991). Some tests of specification for panel data: Monte carlo evidence and an application to employment equations. The Review of Economic Studies, 58(2), 277-297.

Badinger, H. (2005). Growth effects of economic integration: Evidence from EU member states. Review of World Economics, 141(1), 50-78.

Baldwin, R. (1992). Measurable dynamic gains from trade. Journal of Political Economy, 100(1), 162-174.

Baldwin, R., \& Taglioni, D. (2007). Trade effects of the euro: A comparison of estimators. Journal of Economic Integration, 22(4), 780-818.

Berger, H., \& Nitsch, V. (2008). Zooming out: The trade effect of the euro in historical perspective. Journal of International Money and Finance, 27(8), 1244-1260.

8) Even though we cannot argue for significance, one could say that in one out of 6 models the coefficient associated to $\mathrm{EZ}$ is weakly significant.

9) Notice in this case that if the society had not expected any country to join the EZ, the inflation rates may have not fallen prior to the Euro. Thus, the EZ might play a disciplinary role. 
Blundell, R., \& Bond, S. (1998). Initial conditions and moment restrictions in dynamic panel data models. Journal of Econometrics, 87, 115-143.

Bun, M. J. G., \& Klaassen, F. J. G. M. (2002). Has the euro increased trade? Tinbergen Institute Working Paper 02-108/2. Rotterdam: Tinbergen Institute.

Bun, M. J. G., \& Klaassen, F. J. G. M. (2007). The euro effect on trade is not as large as commonly thought. Oxford Bulletin of Economics and Statistics, 69(4), 473-496.

Cavallo, A., Neiman, B., \& Rigobon, R. (2015). The price impact of joining a currency union: Evidence from latvia. IMF Economic Review, 63(2), 281-297.

Cham, T. (2011). Why join a monetary union? Theoretical answers for policy makers in the west african monetary zone (WAMZ). Journal of Economic Cooperation and Development, 32(4), 1-20.

Cottarelli, C., Griffiths, M., \& Moghadam, R. (1998). The nonmonetary determinants of inflation: A panel data study. IMF Working Paper: WP/98/23.

Crespo Cuaresma, J., Ritzberger-Grünwald, D., \& Silgoner, M. A. (2008). Growth, convergence and EU membership. Applied Economics, 40(5), 643-656.

Den Haan, W., J. (2000). The comovement between output and prices. Journal of Monetary Economics, $46,3-30$.

Dreyer, J. K. (2012). Saving based asset pricing models: A contribution to the solution of the equity premium puzzle, Verlag Dr- Kovac, Hamburg.

Dreyer, J. K., \& Schmid, P. A. (2015). Fiscal federalism in monetary unions: Hypothetical fiscal transfers within the Euro-zone. International Review of Applied Economics, 29(4), 506-532.

Dreyer, J. K., \& Schmid, P. A. (2017). Growth effects of EU and EZ memberships: Empirical findings from the first 15 years of the euro. Economic Modelling, 67, 45-54.

Dreyer, J. K., \& Schmid, P. A. (2020). Optimal currency areas and the euro: Business cycle synchronization, Palgrave Macmillan, London.

Dreyer, J. K., Schneider, J., \& Smith, W. T. (2013). Saving-based asset pricing. Journal of Banking and Finance, 37(9), 3704-3715.

Duarte, M. (2003). The euro and inflation divergence in europe. Federal Reserve Bank of Richmond Economic Quarterly, 89(3), 53-70.

Fakher, H. A. (2016). The empirical relationship between fiscal deficits and inflation (Case study: Selected Asian economies). Iranian Economic Review, 20(4), 551-579.

Hall, S. G., \& Lagoa, S. (2014). Inflation and business cycle convergence in the euro Area: Empirical analysis using an unobserved component model. Open Economies Review, 25, 885-908.

Hammermann, F., \& Flanagan, M. (2009). What explains persistent inflation differentials across transition economies? Economics of Transition, 17(2), 297-328

Hendry, D. F., \& Krolzig, H. M. (2004). We ran one regression. Oxford Bulletin of Economics and Statistics, 66(5), 799-810.

Henrekson, M., Torstensson, J., \& Torstensson, R. (1997). Growth effects of european integration. European Economic Review, 41(8), 1537-1557.

Hristov, N., Hülsewig, O., \& Wollmershäuser, T. (2014). Financial frictions and inflation differentials. The Manchester School, 82(5), 549-595. 
Jungermann, H., Brachinger, H. W., Belting, J., Grinberg, K., \& Zacharias, E. (2007). The euro changeover and the factors influencing perceived inflation. Journal of Consumer Policy, 30(4), 405-419.

Kalemli-Ozcan, S., Sørensen, B., \& Yosha, O. (2001). Economic integration, industrial specialization, and the asymmetry of macroeconomic fluctuations. Journal of International Economics, 55(1), 107-137.

Kenen, P. B. (1995). Economic and monetary union in europe: moving beyond maastricht. Cambridge: Cambridge University Press.

Kishor, N., \& Ssozi, J. (2010). Inflation convergence and currency unions: The case of the east african community. Indian Growth and Development Review, 3(1), 36-52.

Krugman, P. (1991). Geography and trade. Cambridge, MA: The MIT Press.

Krugman, P. (1993). Lessons of Massachusetts for EMU. In Adjustment and Growth in the European Monetary Union, edited by F. Torres, \& F. Giavazzi, 241-266. Cambridge: Cambridge University Press.

Landau, D. (1995). The contribution of the european common market to the growth of its member countries: An empirical test. Review of World Economics, 131(4), 774-782.

Levin, A., Lin, C. F., \& Chu, C. S. J. (2002). Unit root test in panel data: Asymptotic and finite sample properties, Journal of Econometrics, 108(1), 1-24.

Maddala G. S., \& Wu, S. (1999). A comparative study of unit root tests with panel data and a new simple test. Oxford Bulletin of Economics and Statistics, 61(1), 631-652.

Mann, K. (2015). The EU, a growth engine? The impact of european integration on economic growth in central eastern europe. FIW Working Paper 136. Bonn: Institute for International Economic Policy.

Motley, B. (1998). Growth and inflation: A cross-country study. Economic Review of the Federal Reserve Bank of San Francisco, 15-28.

Mundell, R. A. (1961). A theory of optimum currency areas. American Economic Review, 51(4), 657-665.

Newey, W. K., \& West K. D. (1987). A simple, positive semi-definite, heteroskedasticity and autocorrelation consistent covariance matrix. Econometrica, 55(3), 703-708.

Roodman, D. (2009). How to do xtabond2: An introduction to difference and system GMM in stata. The Stata Journal, 9(1), 86-136.

Rose, A. K. (2000). One money, one market: The effect of common currencies on trade. Economic Policy, 15(30), 7-46.

Shiamptanis, C. (2010). Did the euro give us a break in inflation? Empirical Economics, 39, 395-411.

Vanhoudt, P. (1999). Did the european unification induce economic growth? Weltwirtschaftliches Archiv, 135(2), 193-220.

White, H. (1980). A heteroskedasticity-consistent covariance matrix and a direct test for heteroskedasticity. Econometrica, 48(4), 817-838.

Windberger, T., \& Zeileis, A. (2014). Structural breaks in inflation dynamics within the european monetary union. Eastern European Economics, 52(3), 66-88. 


\section{Appendix 1: Inflation Rates and Their Determinants}

Table A1. Literature on inflation rates and their determinants

\begin{tabular}{|c|c|c|c|c|c|c|c|}
\hline & $\begin{array}{l}\text { Angeloni, Ehrman } \\
\text { (2007) }\end{array}$ & $\begin{array}{c}\text { Cavallo } \\
(2015)\end{array}$ & Fakher (2016) & $\begin{array}{l}\text { Hammermann, } \\
\text { Flanagan (2009) }\end{array}$ & $\begin{array}{c}\text { Kishor, Ssozi } \\
(2010)\end{array}$ & $\begin{array}{c}\text { Shiamptanis } \\
\text { (2010) }\end{array}$ & $\begin{array}{l}\text { Windberger, } \\
\text { Zeileis (2014) }\end{array}$ \\
\hline Time & & 2013-1014 & $1993-2013$ & 2001-2009 & $1981-2009$ & 1996-2006 & Mid-1990s to 2010 \\
\hline Countries & $12 \mathrm{EZ}$ countries & Latvia & $\begin{array}{l}6 \text { Asian } \\
\text { economies }\end{array}$ & $\begin{array}{l}19 \text { transition } \\
\text { European } \\
\text { economies } \\
\text { (incl. Russia) }\end{array}$ & $\begin{array}{l}\text { EAC } \\
\text { countries }\end{array}$ & 15 EU countries & 21 EU countries \\
\hline Method & $\begin{array}{l}\text { 12-country model } \\
\text { of EZ calibrated } \\
\text { with stylized facts, } \\
\text { modeling each } \\
\text { national economy } \\
\text { with aggregate } \\
\text { supply and } \\
\text { aggregate demand } \\
\text { equation }\end{array}$ & $\begin{array}{l}\text { Analysis of } \\
\text { prices for } \\
\text { thousands of } \\
\text { differentiated } \\
\text { goods of an } \\
\text { international } \\
\text { retail chain }\end{array}$ & $\begin{array}{l}\text { Pooled } \\
\text { model, } \\
\text { Panel-differen } \\
\text { ced GMM }\end{array}$ & $\begin{array}{l}\text { Fixed effects } \\
\text { model, system } \\
\text { GMM for } \\
\text { robustness } \\
\text { check }\end{array}$ & $\begin{array}{l}\text { Unobserved } \\
\text { common } \\
\text { factor model }\end{array}$ & $\begin{array}{l}\text { Structural break } \\
\text { tests }\end{array}$ & $\begin{array}{l}\text { Generalized } \\
\text { logistic model } \\
\text { with structural } \\
\text { break tests and } \\
\text { break-point } \\
\text { estimation } \\
\text { techniques }\end{array}$ \\
\hline $\begin{array}{l}\text { Main } \\
\text { finding }\end{array}$ & $\begin{array}{l}\text { Reasons for } \\
\text { differentials: } \\
\text { Demand shocks, } \\
\text { Cost-push shocks, } \\
\text { Exchange rate } \\
\text { shocks }\end{array}$ & $\begin{array}{l}\text { Adjustment of } \\
\text { retails prices } \\
\text { within two } \\
\text { months after } \\
\text { joining }\end{array}$ & $\begin{array}{l}\text { Identification } \\
\text { of deficit, } \\
\text { GDP, and } \\
\text { exchange rate } \\
\text { with impact } \\
\text { on inflation } \\
\text { rate }\end{array}$ & $\begin{array}{l}\text { Identification } \\
\text { of lagging } \\
\text { internal and } \\
\text { external } \\
\text { liberalization } \\
\text { as obstacle to } \\
\text { disinflation }\end{array}$ & $\begin{array}{l}\text { Inflation } \\
\text { synchronizati } \\
\text { on for } \\
\text { member } \\
\text { countries }\end{array}$ & $\begin{array}{l}\text { Positive breaks for } \\
\text { EZ countries with } \\
\text { higher inflation } \\
\text { rates just after } \\
\text { introduction, no } \\
\text { such breaks for } \\
\text { non-joining } \\
\text { countries }\end{array}$ & $\begin{array}{l}\text { Convergence } \\
\text { toward a lower } \\
\text { mean inflation } \\
\text { rate with reduced } \\
\text { skewness but } \\
\text { higher variance }\end{array}$ \\
\hline
\end{tabular}

(Source) Literature Review

\section{Appendix 2: Data}

\section{Countries}

All original 28 members of the EU from 1997 to 2016: Austria, Belgium, Bulgaria, Croatia, Cyprus, the Czech Republic, Denmark, Estonia, Finland, France, Germany, Greece, Hungary, Ireland, Italy, Latvia, Lithuania, Luxembourg, Malta, the Netherlands, Poland, Portugal, Romania, Slovakia, Slovenia, Spain, Sweden, and the United Kingdom.

\section{EZ membership and announcement}

We defined the variable EZ membership by setting them equal to 1 in case of membership and 0 for nonmembership. The variable announcement (Ann) is set to one in the prior three years of EZ membership. 


\section{Total government debt}

The total debt was collected from Eurostat, OECD, and IMF because the total series could not be collected from only one source. Eurostat has data available since 2005. The rest of the data was collected from the OECD and IMF databases. Afterward, we divided by the total GDP in current prices to get the data series in percentage terms of the GDP.

The next variables were collected from the International Monetary Fund, World Economic Outlook Database, April 2017.

\section{Inflation}

According to the IMF database, the data collected on inflation is given by the percentage change at the end of period consumption prices (Index) of the different countries.

\section{Current account balance}

The current account balance was collected as percentage of the country's GDP.

\section{Balance of govemment budget}

The balance of government budget was collected as percentage of GDP directly from the time series: general government net lending/borrowing.

The next variables were collected directly from the Eurostat home page.

\section{Unemployment}

The unemployment rates collected are calculated as the percentage of unemployed persons in the total labor force, which is the total of people employed and unemployed. The classification of unemployed according to Eurostat is "Unemployed persons aged 15 to 74 who were: a. without work during the reference week, b. currently available for work, i.e., were available for paid employment or self-employment before the end of the two weeks following the reference week, c. actively seeking work, i.e., had taken specific steps in the four weeks period ending with the reference week to seek paid employment or self-employment or who found a job to start later, i.e., within a period of, at most, three months."

\section{GDP growth}

The GDP growth was collected as the annual percentage change on previous year's GDP in Euros of 2005. 


\section{Investment and govemment spending}

We collected data on gross fixed capital formation and final consumption expenditure of general government as percentages of the GDP. One can find these data series under "GDP and main components - Current prices [nama_gdp_c]."

\section{Appendix 3: Unit Root Tests with Panel Data}

We checked whether all variables of Eq. (2) are stationary by running the tests of unit root for panel models of Maddala-Wu (1999) and of Levin, Lin, and Chu (2002). The hypothesis of non-stationarity can be rejected for all variables at the $1 \%$ significance level except for the balance of current account, which rejects the hypothesis of unit root in this case at the $5 \%$ significance level.

Table A2. Unit root tests with panel data

\begin{tabular}{ccc}
\hline Variable & \multicolumn{2}{c}{$p$-values } \\
\cline { 2 - 3 } & Maddala-Wu & Levin, Lin, and Chu \\
\hline$r_{t, i}$ & $<0.01$ & $<0.01$ \\
$I N V_{t, i}$ & $<0.01$ & $<0.01$ \\
$S_{t, i}$ & $<0.01$ & $<0.01$ \\
$U_{t, i}$ & $<0.01$ & $<0.01$ \\
$G O V_{t, i}$ & $<0.01$ & $<0.01$ \\
$C u r r_{t, i}$ & $<0.01$ & $<0.01$ \\
$D e b t_{t, i}$ & $<0.01$ & 0.0489 \\
\end{tabular}

